\title{
Venus transits - A French view
}

\author{
Suzanne Débarbat
}

Observatoire de Paris, SYRTE/UMR 8630, Paris, France

\begin{abstract}
After a careful study of Mars observations obtained by Tycho Brahé (1546-1601), Kepler (1571-1630) discovered the now-called Kepler's third law. In 1627 he published his famous Tabulae Rudolphinae, a homage to his protector Rudolph II (1552-1612), tables (Kepler 1609, 1627) from which he predicted Mercury and Venus transits over the Sun. In 1629 Kepler published his Admonitio ad Astronomos... Advertisement to Astronomers (Kepler 1630), Avertissement aux Astronomes in French Au sujet de phénomènes rares et étonnants de l'an 1631: l'incursion de Vénus et de Mercure sur le Soleil. This was the beginning of the interest of French astronomers, among many others, in such transits, mostly for Venus, the subject of this paper in which dates are given in the Gregorian calendar.
\end{abstract}

\section{The 1631 and 1639 Venus transits}

The predicted Mercury transit being the first to occur, Gassend (1592-1655), frequently known under the form Gassendi, then a professor in the south of France, later to be a professor to the Collège Royal in Paris, decided to observe it. Being a friend of Peiresc (1580-1637) he was introduced to astronomy and to Kepler's elliptic orbits. Confident in the prediction, he began (being in Paris at that time) with Mercury, on November 7, and succeeded with a solar image having a diameter of $24 \mathrm{~cm}$. Gassend made a careful study of his data; his conclusions were favourable to elliptic orbits and Kepler's tables, but he considered that Kepler was in error for the conjunction.

Gassend (1632) decided to observe the Venus transit, on 1631 December 6 as predicted, despite the fact that Kepler had written that it could not be seen from Europe. From a map, established by Jean Meeus, it can be seen that the transit could be observed only from Asia. From better ephemerides it was seen, during the XVIIIth century and later, that the conjunction occurred only on December 7, and that it was close to the limb of the Sun.

In the "Advertisement to Astronomers" the next predicted Venus transit could occur only in 1761, the 1639 one being only a close approach. With no success in 1631, the French astronomers went into other fields. Gassend and Peiresc began observations of the satellites of Jupiter discovered by Galileo Galilei (1564-1642), having in view predictions for improving the determination of longitudes.

Meanwhile, following a revision of Kepler's Tables, young Horrocks (1618/19-1641) and his friend Crabtree (1610-1644) were the only ones in Great Britain, and in the world, to observe the 1639 December 4 transit of Venus (Horrocks 1672). From the corresponding Meeus map, conditions were favourable, even with a more-or-less cloudy day, as it was.

This success caught the attention of many Europeans. The Scottish Gregory (16381675), so well known by his reflector, mentioned in his book published in 1663 the capability, from any Mercury or Venus transits, to determine the solar parallax. Having in mind the 1677 Mercury transit, astronomers had to wait.

In France, the Observatoire Royal, created in 1667 by Louis XIV, was under construction. The following year the astronomers suggested the invitation of Cassini (1625-1712), 
this astronomer and professor in Bologna having published his high-level tables for the prediction of the eclipses of the Galilean satellites of Jupiter. In 1669/70, Picard (1620-1682) measured a terrestrial arc along the Paris Observatory meridian line using a portable quadrant, a zenith sector and a level equipped with refractors and with the micrometer he had devised with Auzout (1622-1691).

Having deduced from these measurements the dimension of the Earth, the astronomers could think about the solar parallax. This was made using Mars observations from Cayenne (Guyana) by the French astronomer Richer (1630-1696) and from Paris by Cassini. While Horrocks, from the diameter of Venus, had multiplied by a factor of 4 the Sun-Earth distance established by Copernicus (1473-1543), the new measurements brought this to a factor of 20 in 1672 .

One year before the 1677 Mercury transit the Danish astronomer Roemer (1644-1710), then in the Paris Observatory, employing the eclipses of the satellite Io observed from 1666 to 1676, discovered the fact that light has a finite speed. The same year, 1676, began the mapping of the west French coast, by Picard and La Hire (1640-1718), using as a reference the Paris Observatory meridian.

Such were the works performed by the French astronomers when, as we say in French, "Halley vint". In England the first Astronomer Royal, Flamsteed (1646-1719) was installed in the Royal Observatory (nowadays the Royal Observatory Greenwich), created in 1675. A young assistant, Halley (1656-1642), was sent to the southern hemisphere to improve cartography and navigation (Cook 1998; Halley 1981). When on the Island Saint-Helena he observed on 1677 November 7 a Mercury transit, with a 24-foot refractor. Having a good pendulum clock, equipped, as made by Huygens (1629-1695) in the LowCountries, Halley could obtain the duration of the complete phenomenon. This brought him to consider the following year that Venus could be of better use to determine the solar parallax (Toulmonde 2001). But, according to Kepler, the next such transit was to occur in 1761, giving plenty of time to the astronomers.

\section{The 1761 and 1769 Venus transits}

The interest of astronomers (Van Helden 1985) came through the various studies made by Halley (from 1720 the second Astronomer Royal). His important publication Methodus singularis..., published in 1716 in the Philosophical Transactions, was translated into English by Ferguson (1710-1776), in his book "Astronomy" published one year before the 1761 transit. The first translation of Halley's paper into French was recently published in the magazine l'Astronomie, in a translation made by Bonche \& Toulmonde (2001). The French complete title given is Méthode singulière pour déterminer la parallaxe du Soleil ou sa distance à la Terre par les observations de Vénus dans le Soleil, proposée devant la Royal Society par Edmond Halley, Docteur dans les Deux Droits, secrétaire de la Société.

However, 1761 was far from 1716; the astronomers had a time to wait, but Halley's method was given. While the Greenwich astronomers had duties regarding improvements for astronomy and navigation, in France they were busy with the consequences of Newton's Principia and with a general map of France. In Greenwich, Bradley (1693-1762) deduced, from his positional observations, nutation and aberration, while his colleagues were working on the lunar distances method for navigation, and the horologer Harrison (1693-1776) on his marine clocks.

In France, the Cassinis, Lacaille (1713-1762) and others established the reference meridian line from Dunkirk to the Pyrenees. In 1750 Lacaille (ms: "Avis aux astronomes") departed to the Cape of Good Hope with several purposes, among them the parallax 
of Mars and of the Moon; for the success of this work, he requested his colleagues from many countries to perform similar observations. In a note to this call, Lacaille spoke about Halley's proposal and, mostly, about the error he had given which appeared to him rather small, given the difficulties in the observations.

Having observed Mercury transits in 1723, 1736, 1743 and 1753, the astronomers were still waiting for the 1761 Venus transit. But they had also made studies about the best possible method for the determination of the solar parallax from Venus (Woolf 1959; Dumont 2001). Halley had assumed that the accuracy for the timings of contacts could be less than one second of time, asking his colleagues to observe on a more-or-less international level. But, Halley having died in 1742, Delisle (1688-1768), who had met him in 1724 during his voyage in England, recalled Halley's idea. He also suggested, instead of using the duration of the transit from two stations, to observe the timing of the same contact from such places.

In April 1760, Delisle gave to the Académie des sciences a "Mémoire" with a more complete study than his previous papers published in 1723 and 1743 (Delisle 1743). He also made a "Mappemonde" showing the best observing places. Despite the fact that he made copies of the mémoire and that 200 maps were sent around the world, none of the maps can be found in France. The best known 1761 map is the one published by Ferguson "A Plain Method" in 1760. Sent well in advance to his correspondents, Delisle's map and mémoire reached their destinations and almost every one agreed to do his best.

The British and the French appeared as the most concerned by the phenomenon. In France it was observed by Maraldi (1700-1788) at the Paris Observatory, Lalande from the Palais du Luxembourg, Jeaurat (1724-1803) at the Observatoire de l'Ecole Militaire, Messier (1730-1817) from the Observatoire de la Marine, then situated in what is now named Hôtel de Cluny and Musée du Moyen-Age in the Quartier Latin. Lemonnier (17151799) and La Condamine (1701-1774) were with Louis XV who requested astronomers to see the phenomenon.

Many others in France made similar observations (Mém. Acad. Sci. 1763), while four teams were sent abroad: Le Gentil de la Galaisière (1725-1792) was at sea on June 6, trying to observe from the boat; Chappe d'Auteroche (1728-1769), upon invitation from the empress Elisabeth II (1709-1762) of Russia, was in Siberia, in Tobolsk, observing the transit after the first two contacts (Chappe d'Auteroche 1763); Pingré (1711-1796) went to the "Ile Rodrigue" close to "Isle de France", nowadays "Ile Maurice" or Mauritius Island and could observe the whole transit (Pingré 1763); Cassini III (1714-1784) was in Europe, in Vienna (Débarbat \& Dumont 1996), to observe with Father Liesganig (1719-1799) and the Archduke Joseph (1741-1790).

¿From 62 stations, the French Academy of sciences received about 120 reports giving values of the solar parallax lying between 8."6 and $10{ }^{\prime \prime} 6$. With such a difference, far more that thought by Halley, the astronomers were not satisfied. A better international organisation appeared to be needed with an improved location of the stations. Delisle decided, in 1763, to leave the Hôtel de Cluny to Messier. Lalande (1762) had already given over the call to his colleagues, establishing a 1769 map and delivering it to the Académie in May 1760. It was published in 1762 (in the 1757 issue) together with his mémoire; there is apparently no written proof that Mme Lepaute (1723-1788) made the 1769 map, while she made so many calculations clearly mentioned by Lalande.

After only 8 years, most of the 1761 observers were ready for 1769. As examples, Messier was at the Collège Louis-le-Grand in Paris, Maraldi and Cassini at the Observatory, while Le Gentil, Chappe d'Auteroche (1772) and Pingré (1767) were abroad: Le Gentil (1778), who had decided to stay in the Indian Ocean, receiving orders from France, was in Pondicherry in due time, but the sky had some clouds and, back in France, he wrote a 
book concerning his long voyage and his scientific works between 1760 and 1771; Chappe d'Auteroche went to California and was able to observe the complete transit before his death on August 1, but his results were not lost due to his collaborators; Pingré was the third astronomer, being a specialist for checking at sea chronometers made by Berthoud (1727-1807); after his 1761 trip for the transit, he made four more voyages and was in Saint-Domingue in 1769, being able to catch the Venus transit at its beginning.

From 63 stations the French Académie des sciences received about 150 reports, mostly through Lalande in a similar way as Delisle for the 1761 transit. The results lie between 8." 43 and 8." 80 . Lalande, in his careful study, reduced the solar parallax to values between 8."55 and 8.'63. The result being not so precise as expected, many astronomers made deep studies of the 1761 and 1769 transits. As examples: Delambre (1749-1822) with 8.'55; Laplace (1749-1827) with 8.'81; Encke (1791-1865), in Germany, with 8.'57. The improvement is far less than expected and other methods began to appear for the determination of the solar parallax.

Nevertheless, astronomers from all over the world, having assumed for this parallax values between $8 . " 5$ and 8." 8 , and having by mid-XIXth century better instruments, including photographic techniques, they began to think about the next Venus transit. They took into account the fact that more precise local values of the coordinates of the stations were needed to improve the accuracy of the results. With their modern instruments, they could obtain them accurately for longitude and latitude.

\section{The 1874 and 1882 Venus transits}

The Académie des sciences began to think, in 1870, of a national commission for the 1874 transit, and called several academicians to be its members such as Laugier (18121872) and Delaunay (1816-1872) from Paris Observatory. But they died in 1872. Puiseux (1820-1883) was the secretary of the commission, while Le Verrier (1811-1877) and others were among its members. In 1873 Dumas (1800-1884) was called to be its president and Fizeau (1819-1896), a physicist of a very high level reputation, was in charge of the photographic aspects. He installed in the Luxembourg garden all that was needed for the photographers with an equatorial refractor. Another one was set up on the upper platform of the Luxembourg palace while an artificial Venus transit was taking place on the roof of the Paris Observatory, not far away.

All the stations were to be equipped with two equatorial refractors together with instruments for hydrography, geophysics and meteorology. Two stations were chosen in the southern hemisphere: Ile Campbell with Bouquet de La Grye (1827-1909) and Ile Saint-Paul with Mouchez (1821-1892) who gave details in "Passage de Venus ... 1874" (Mouchez, no date). Two were chosen in the northern hemisphere: Peking with Fleuriais (1840-1895), a marine officer, and Japan with Janssen (1824-1907). Two more stations, not so well equipped, were decided later: Saigon with Héraud, an engineer and hydrographer, and Nouméa with André (1856-1927).

Most of the expeditions departed in July 1874, the helpers having left France in April with the equipment, while the scientists were with the scientific instruments which number was more than 30. The equipment was more or less the same for five stations. Janssen - under the direct leadership of the Académie - decided to experiment a new instrument he called a revolver, later a revolver photographique with daguerréotype. His first model was built, in 1873, by Deschiens. But Janssen was not satisfied; he requested the Rediers, in 1874, to built a new one. This last original model is in the collections of the Paris Observatory and in exhibition on the occasion of the 2004 June 8 transit of Venus. A paper was published by F. Launay (2001) in the May issue of l'Astronomie, and an 
extended one, in English, is under final preparation. A third model was made by the Rediers and given, after his death, by his daughter Antoinette, to the Conservatoire des Arts et Métiers. There are experimental plates in the Paris Observatory but, unfortunately none of the real plates has been found, up to now.

Having been informed about the new apparatus Airy (1801-1892), the Astronomer Royal at that time, asked Dallmeyer, in England, to build some Janssen's revolvers, while De La Rue (1815-1889) decided to build others. One is preserved in the Sydney Powerhouse Museum. In total, according to Launay, 9 Janssen's revolvers were in use in the world in 1874. This employment is responsible for the development of Marey's work (Marey, 1853-1904) followed by the films and the cinema. Tisserand (1848-1896) was, with Janssen, in charge of the determination of the coordinates of the station and responsible for the chronometers (Saito \& Shinozawa 1973).

After the campaign the derived results gave to the solar parallax values such as 8. $80 \pm 0$.' 06 and 8.' $85 \pm 0$.'06, while the astronomers had estimated the error at only \pm 0 ' 01 . After the 1761 and 1769 campaigns and the careful studies made later, in various countries, the most probable value was given between $8 . .5$ and 8." 8 . For Lalande, as already mentioned, it was between 8."55 and 8.'63. Not so different from what was given one century later for 1874. This explains why, at national and international levels, astronomers wanted to increase cooperation for the following transit to occur in 1882 and visible from Europe, but only at its beginning.

In view of this 1882 event, the Académie des sciences decided to do its best to increase the number of observing sites and the international cooperation. Under the name Conférence internationale du passage de Vénus (1881), the meeting took place in 1881 October 5 at the Paris Observatory the director of which, after the death of Le Verrier who died in 1877, was Admiral Mouchez.

Among the French attendees were most of those having been in the 1874 expeditions such as Tisserand, Bouquet de la Grye, d'Abbadie, Fleuriais, Hatt, Le Clerc, Perrier, Perrotin. Were also present from other countries and from observatories, Foerster (Berlin), Weiss (Vienna), Hirsch (Neuchatel), Liais (Rio de Janeiro), Puzajon (San Fernando), Stone (Oxford) and Van de Sande Bakhuysen (Leiden). There were also present delegates from several countries, other than those already mentioned: de Azcarate (Spain), Broch (Norway), Govi (Italy), Mansila (Argentina), Moesta (Chili), Oudemans (Low Countries), Pechele (Denmark) and Viegas (Portugal).

The president was Dumas proposed by Italy as the president of the similar French commission. The two vice-presidents were Foerster and Weiss, the two secretaries were Hirsch and Tisserand. Great Britain, who had organized, in 1881, a committee for the 1882 Venus transit, under the chairmanship of Stokes, had sent to Paris one of its members, Stone; he informed the members that the British committee had decided to provide 16 teams located in 6 different spots.

At the Paris international meeting many questions, already raised at various national levels, were discussed, mostly based on the 1874 transit and on new experiments made on Mercury. Comparisons of success or difficulties were also under discussion; decisions taken at national levels were presented. They mostly concerned photography, including British, German, French comments. Proposals for the national stations were given by the delegates of each country. Several sub-commissions were created for the places of stations, the instruments and the observational methods, together with the organization of reductions of the collected data.

On the last day of the meeting, October 13, several proposals were adopted by the members of the commission, including a text about the instructions for the observations of contacts. These proposals were sent to Governments which were to be free to follow 
or not to follow the content. A Table of the result, concerning the stations and their locations, was established and the complete report printed and sent all over the world.

For France several missions were sent: Cuba, under d'Abbadie (1810-1897) (whose private Observatory in Abbadia, close to Hendaye in the far south of France, has to be visited) with Callandreau (1852-1904) from Paris Observatory, the marine officer Chapuis (1843-1889) for photography and de La Baume Pluvinel (1860-1938) in an independent station; Martinique under Tisserand with Bigourdan (1851-1932) from Paris Observatory and, among the instruments, a heliometer; Florida under colonel Perrier (1833-1888); in Mexico Bouquet de La Grye and Héraud who were in one of the 1874 mission; Chili, a marine officer de Bernardières. Argentina received in Santa Cruz Fleuriais (1840-1895), in Chili went Hatt (1840-1915), in Rio Negro Perrotin (1845-1904) also with a heliometer; Argentina installed in Bragado a station to which the marine officer Perrin (1852-1926) was added. Being in Cape Horn, the marine officer Courcelle-Seneuil was asked to attempt the observation on December 6 (Passage de Vénus ... 1883).

The disappointment was great in all countries (Sellers 2001), the results being not so accurate as the astronomers thought. From the observations Newcomb (1835-1909), using the 1761 and 1769 transits, had obtained for the solar parallax, 8.'79 \pm 0 "'05. Adding the 1874 and the 1882 Venus transits he gave $8 . .79 \pm 0 . \prime 02$ in 1891 . Not yet \pm 0. . 01 as obtained by Gill (1843-1914), with the planet Mars at the 1877 opposition, with a concluded value 8. " $78 \pm 0$. .'01.

In 1896, during the meeting of the Conférence internationale des étoiles fondamentales, held at the Paris Observatory, it was decided to fix the solar parallax at a more or less mean value issued from all the previous results. Included were old French data for 1761 and 1769, and the recent ones from 1874 and 1882, derived from all recent campaigns, together with other methods. The adopted value, to make the astronomical constants uniform, to be used in the ephemerides, was fixed at $8 .{ }^{\prime \prime} 80$.

The discovery of the small planet (433) by Witt (1866-1946) in 1898, named Eros, showed that this body could approach the Earth at only 0.15 astronomical units, instead of about 0.37 for Mars and 0.26 for Venus. An international campaign was launched for the close 1900/1901 approach with a meeting in Paris. Loewy (1833-1907), then director of the Paris Observatory, was in charge of the compilation of the data to derive the solar parallax, but he died in 1907 before the end, and the report was finalized by the British astronomer Hinks (1873-1945) and printed (Hinks 1901) under the title: Rapport sur la détermination de la parallaxe solaire au moyen des observations de la planète Eros, faites dans les années 1900 et 1901.

But this is no longer the story of the Venus transits.

\section{Final remarks}

To conclude some French reliefs, left for the people of any time, are mentioned:

- A medal made after the 1874 transit and offered to all participants of the Conférence internationale du passage de Vénus held in Paris in 1881.

- In some places there are symbolic pieces related to the XIXth century transits. Two examples: in Saint-Paul with a special stone and in the surroundings of Nagasaki, the pyramid erected more than one century ago and still there.

- A ceiling in an octagon room on the first floor of the Perrault building of the Paris Observatory installed in 1886. Looking at it carefully are seen the Sun, Venus, a small Cupidon with an arc and an arrow, amours or angels observing, submitting elements to Urania or ready to announce, with a horn, the phenomenon. Also seen are, in a golden medal, Halley, as a homage to his call to observe Venus transits, Delisle in a silver one 
and, facing them, Le Verrier who had made a study of about 9000 values of the solar diameter. A description of this ceiling follows in the next section in French.

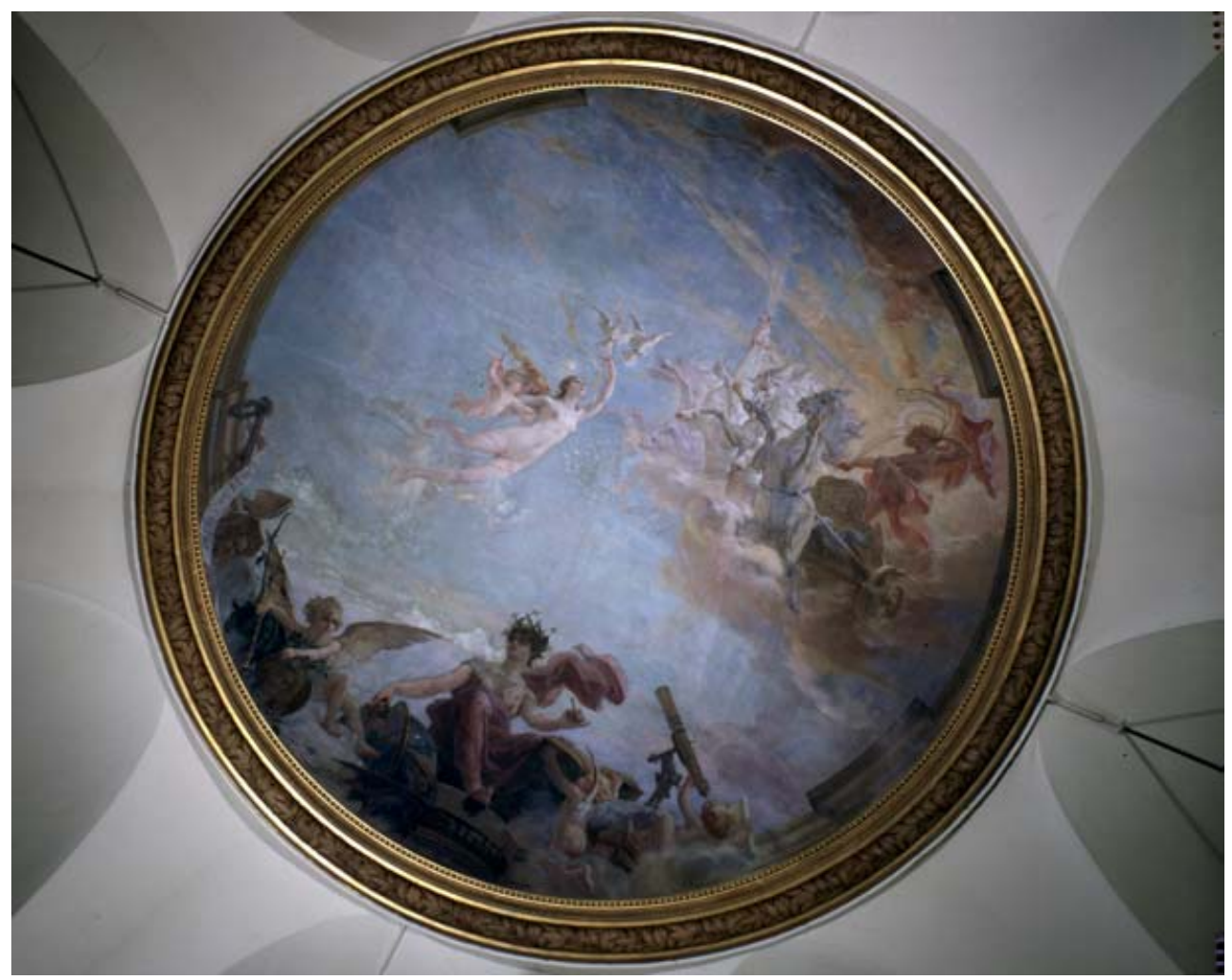

Figure 1. The painting by Dupain (1847-1933) that decorates the ceiling of the octagonal west rotunda of the Perrault Building of the Paris Observatory showing an allegory of the passage of Venus over the sun. Copyright Paris Observatory.

\section{Allégorie du passage de Vénus devant le Soleil}

La peinture, œuvre de Dupain (1847-1933), orne le plafond de la Rotonde Ouest, de forme octogonale, du Bâtiment Perrault de l'Observatoire de Paris. L'Amiral Mouchez, qui en est alors directeur, souhaite créer un décor dans cette partie du rez-de-chaussée du bâtiment oú il a fait installer, à partir de 1879, certains des instruments les plus prestigieux des collections. D'une part, il fait réaliser les portraits des astronomes qui se sont trouvés, au cours du temps, à la tête de l'Etablissement. D'autre part, il envisage un plafond décoratif, représentatif de travaux qui y sont menés. Il envisage, dès 1880 , une allégorie du passage de Vénus sur le Soleil. Il a lui-même observé un tel passage en 1874 et un autre doit se produire en 1882 .

En 1884, Dupain essaye sur place son esquisse du Passage de Vénus dans cette salle, la peinture, de grande dimension, devant y prendre place en 1885. En fait elle ne le sera qu'en octobre 1886, ayant - dans l'intervalle - figuré dans une exposition. Le Soleil, sur son char attelé de chevaux bondissants, est entouré de vapeurs et de nuées rougeoyantes. Vénus, nue et la tête surmontée d'une étoile, est entrainée dans une belle envolée par deux oiseaux blancs tenant en leurs becs les fils qui l'emportent. Accompagné d'un petit 
Cupidon portant arc et flèche, cet ensemble baigne dans des nuages clairs d'une grande légèreté.

Au bord de l'allégorie, au pied de ces personnages, Dupain a placé, au centre assise sur un pilier, Uranie la tête couronnée de lauriers et d'étoiles. Sa main gauche s'appuie sur un globe terrestre oú se devinent les continents. Sa main droite tient du matériel d'écriture au-dessus d'un grand registre ouvert, que lui présente un autre angelot. Deux autres volumineux et beaux ouvrages, représentés plus à gauche, sur lesquels s'appuie un nouvel angelot soutenu par un nuage blanc et vaporeux, contiennent certainement les données de prédiction des éléments du passage de Vénus. Dans sa main gauche il tient un document, noué d'un ruban, tandis que, de sa main droite, il manipule la vis d'entrainement de l'oculaire d'une petite lunette, à monture équatoriale, avec laquelle il observe Vénus.

A droite de cette partie de l'allégorie un troisième angelot, aux belles ailes déployées, tient dans sa main gauche une trompette de la renommée en prévision, sans doute, de l'annonce de l'instant précis du phénomène. Son bras droit s'appuie sur une médaille d'or, qu'il couvre de lauriers, représentant Halley. A droite Delisle figure en médaille d'argent et, un peu plus à droite, leur faisant face, c'est Le Verrier, lequel a mené une étude portant sur plus de 9000 valeurs du diamètre du Soleil, que l'on reconnaît. Un bandeau "Passage de Vénus" lui fait suite avec une partie d'ancre de marine débordant d'un soubassement en pierre blanche.

\section{References}

Bonche E., Toulmonde M., La Méthode de Halley, in l'Astronomie, vol. 118, p. 314-318, 2001.

Chappe d'Auteroche J., extract of a travel in Sibérie, pour l'Observation de Vénus sur le disque du Soleil, faite à Tobolsk le 6 juin 1761, Mémoires de l'Acad. Sci., p. 337-377, 1751, publ. 1763.

Chappe d'Auteroche J., Voyage en Californie..., written and published by M. de Cassini fils, Paris, Jombert, 1772.

Cook A., Edmond Halley - Charting the Heavens and the Seas, Clarendon Press, Oxford, 1998.

Conférence internationale du passage de Vénus, Procès-verbaux, Imprimerie Nationale, 1881.

Débarbat S. et Dumont S., Deux pélerins de la cartographie scientifique en Europe centrale et orientale, in $X Y Z, \mathrm{n} 67$, p. 70-76, 1996.

Delisle J.-N., Extrait d'une lettre de M.Delisle, écrite de Petersbourg le 24 Août 1743, et adressée à M. Cassini Servant de supplément au Mémoire de M. Delisle de 1723, p. 105, pour trouver la parallaxe de Mercure dans le disque de cet Astre, Histoire et Mémoires de l'Académie des sciences, partie Mémoires, p. 419-428. et planche XI, 1743.

Dumont S., Les expéditions du XVIIIe siècle pour les passages de Vénus, in l'Astronomie, vol. 118, p. 290-295, 2001.

Gassendi P., Mercurius, in Sole visus et Venus invisa anno 1631, Paris, 1632.

Halley E., The three Voyages of Edmond Halley, in the Paramore 1698-1701, Ed. N. Thrower, The Hakluyt Society Publ., Londres, 1981.

Hinks A., Rapport sur la détermination de la parallaxe solaire au moyen des observations de la planète Eros, faites dans les années 1900 et 1901, Carte du Ciel I, sn, sd.

Horrocks J., Excepta ex Epitolis Jerem. Horroccii ad Gul. Crabtrium..., Londres, œuvre posthume, 1672, part Observationes Célestes HabitæToxyethæ, propè Liverpoliam ANGLI, a JEREMIA HORROCCIO, several editions.

Kepler J., Astronomia nova..., Pragae, 1609.

Kepler J., Tabulæ Rudolphinæ..., Ulm, 1627.

Kepler J., Admonitio ad astronomos..., Leipzig 1629, édition consultée Frankfurt, 1630.

Lacaille N., Avis aux astronomes. . . à l'occasion des observations. . hémisphère austral, Imprimé de 4 pages, Manuscrits A 6.9 de la Bibliothèque de l'Observatoire de Paris. 
Lalande J., Mémoire sur les passages de Vénus...1761 et 1769...., Académie des sciences Mémoires, p. 232-250, 1757, publ. 1762.

Launay F., Le revolver photographique de Jules Janssen, in l'Astronomie, vol. 118, p. 306-308, 2001.

Le Gentil de La Galaisière G., Voyage dans les mers de l'Inde..., Paris, 1778.

Mémoires de l'Académie des sciences, volume de 1751 publ. 1763: numerous observations; among them Lemonnier (with Louis XV, Château de Saint-Hubert), Maraldi (Observatoire de Paris), Lacaille (Conflans-sous-Carrières), Lalande (Palais du Luxembourg), ...

Mouchez E., Passage de Vénus sur le Soleil du 9 décembre 1874, nl, nd.

Passage de Vénus sur le Soleil du 6 décembre 1882 - Rapports préliminaires, 1883.

Pingré A., Observation du passage de Vénus devant le disque du Soleil le 6 juin 1761, faite à Rodrigue dans la mer des Indes, Mémoires de l'Acad. Sci., p. 87, suivi de Remarques de Lemonnier, p. 88-89 et 105-111, de Lalande, p. 93-95 et 111-112, puis Pingré J., Observations astronomiques pour la détermination de la parallaxe du Soleil, faites en l'isle Rodrigue, p. 413-486, Vol 1761, publ. 1763.

Pingré A., Mémoire sur le choix... passage de Vénus du 3 juin $1769 \ldots$, Lu à l'Académie des sciences en décembre 1766, en janvier et en février 1767. Cavelier Libraire, 1767.

Saito K. et Shinozawa S., On the Observations of the Transit of Venus over the Sun with Particular Emphasis on the december 9, 1874 Event observed in Japan (en japonais), Tokyo Astronomical Observatory Ed., 1973.

Sellers D., The transit of Venus, Maga Velda Press, 2001.

Van Helden A., Measuring the Universe. Cosmic Dimensions from Aristarchus to Halley, Chicago and London, 1985.

Toulmonde M., La parallaxe du Soleil, in l'Astronomie, vol. 118, p. 274-289, 2001.

Woolf H., The Transits of Venus - A story of eighteenth-century science, Princeton University Press, 1959.

\section{Discussion}

DAvid SELlers: I have seen papers by Delisle from the 1720s and the 1750s right up to the eve of the 1761 transit explaining how to calculate the solar parallax from the transit, but when you read them they all seem to be Halley's method, which was based on measuring the duration. Do you know when Delisle actually came up with the method that bears his name, which only requires the measurement of the time?

Suzanne DÉBARBAT: For Halley it is the timing between the contacts observed from two different stations, while for Delisle it is the measurement of the same contact - the timing - from different places. He began to think of that after he had visited Halley in 1724. Delisle went to England - as far as I remember he met also Newton - and he met Halley, and they discussed it. He began to think of the subject in 1723 before meeting Halley. He departed from France in 1723 for Russia, and during the time he was in Russia he thought also on the matter and he published a paper in 1743 - the final paper is the one I have mentioned. So you see I have a feeling that he was thinking of the different possibilities to determine the solar parallax from different places during the time he was in Russia. Was it exactly what you wanted to know?

DAVID SELLERS: Yes, although I thought the 1743 paper was still explaining more or less Halley's method, rather than his own. I was just wondering how late it was that Delisle actually came up with that unique method of his.

SuZAnne DÉBARBAT: I don’t know more.

DAvid Hughes: The Delisle method is of course only half as good as the Halley method, because the inaccuracy of the Delisle method is ... 
Suzanne DÉBARBat: I don't know. I'm not sure that the accuracy is so much less; do you think so?

David Hughes: Oh, yes.

Suzanne Débarbat: You have tried some calculation? Done an experiment?

DAvid Hughes: It's exactly half as ...

Suzanne DÉBARbat: But Halley's method is not so accurate as he thought.

DAvid Hughes: Halley's method depended entirely on this timing and of course ...

Suzanne Débarbat: Oh, yes!

DAvid Hughes: Well, what fascinated me about Halley was he thought that the clocks would be good enough to give an accuracy of 1 second, and then of course the black drop effect ...

Suzanne DÉBARBat: I have heard in some place half a second about Halley. Did you find that? I've seen half a second for the timing of the contacts.

DAvid Hughes: Well, if his accuracy was half a second he would have got the astronomical unit to one part in a thousand; and as it was an accuracy, I thought, of just 1 second that's were his one part in 500 came from.

STEve Dick: Can you say any more about the French photographic method in 1870. I believe it was the same as the American: the long focus photographic method.

SuzAnne DÉBARBAT: I don't remember for the photographic plate; they had a 6 -ft and an 8-ft, but I cannot remember which one was for the contact and which one was for the photographic plate. It is said in the paper itself which one was used for the photographic plate, but it could be only 6 or 8 .

Steve Dick: The Americans used a 40-foot photo-heliograph to get the scale ... the long focus. 


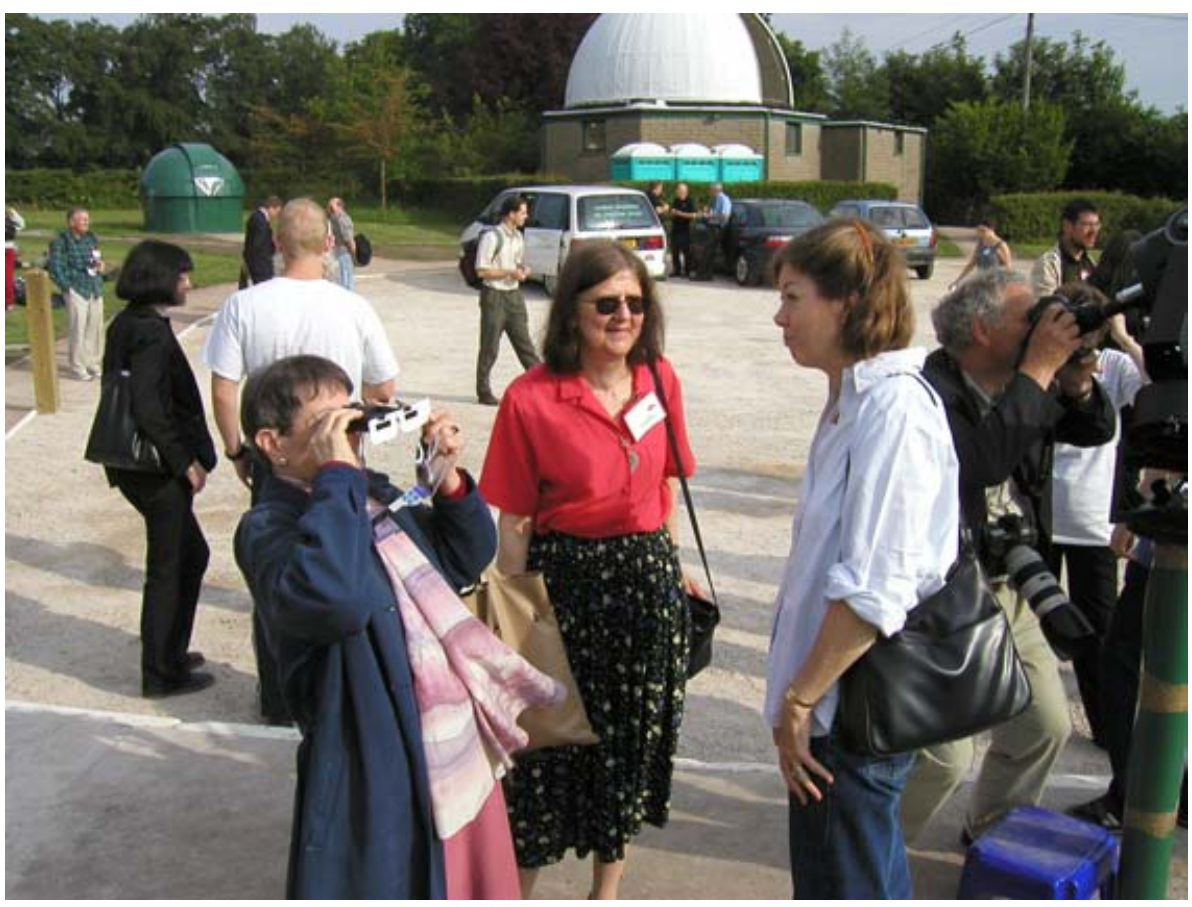

Suzanne Débarbat viewing the transit; Nicole Capitaine and June Kurtz

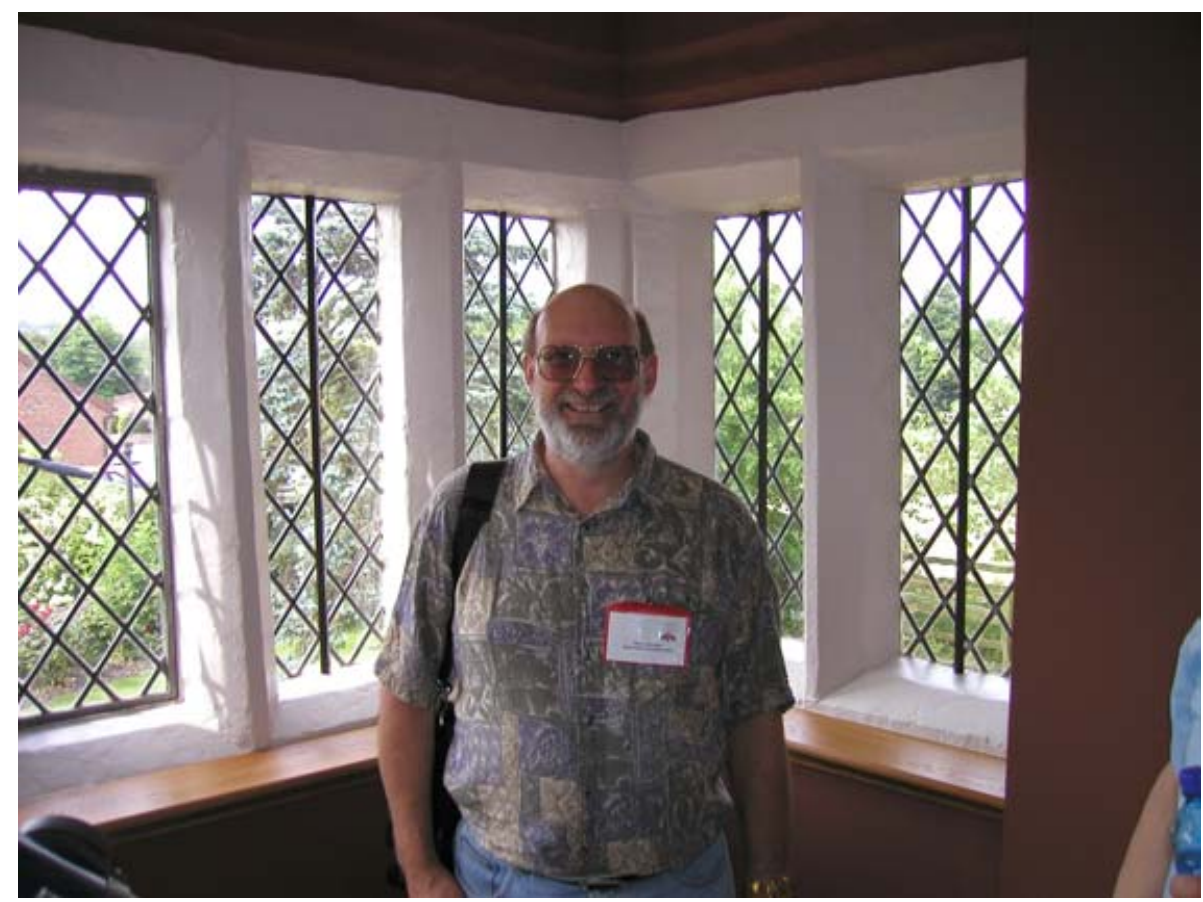

Wayne Orchiston at the window of Carr House from which it is thought that Jeremiah Horrocks observed the 1639 transit. 